\title{
Productivity Assessment of Bakery Firm in Khulna Region Of Bangladesh
}

\author{
Fariha Farjana ${ }^{1}$, Md. Abu Rayhan ${ }^{2}$ \\ ${ }^{1}$ Lecturer, Economics Discipline, Khulna University, Bangladesh. \\ ${ }^{2}$ Economics Discipline, Khulna University, Bangladesh.
}

\begin{abstract}
Manufacturing firms are playing a dominant role for economic development of Bangladesh after it's independence. Bakery firms are considered as an important part of manufacturing firms. In this paper authors analyzed the productivity status of bakery firms. Labor, capital, raw materials and energy are used as input for analysis of the productivity of bakery firms. The data provide strong evidence of increase in output if raw materials are available. If labor, capital and energy held constant al percent increase in raw materials increase output by 0.775percent. It is significant at 1percent significant level. The joint hypothesis tests proof that input and output are not unrelated. The returns to scale assessment manifests presence of increasing returns to scale in bakery firms. The firms also experiences availability of cheap inputs. It is one of the key factors for expansion of bakery firms in Khulna region of Bangladesh. Owners of baking firms should give more emphasize on wealth maximization rather profit maximization. If it is possible to nourish bakery firms properly, in near future it will contribute a dominant role in boosting the GDP of Bangladesh.
\end{abstract}

Keywords: Bakery firms, Cobb-Douglas production function, input, output, returns to scale

\section{Introduction}

After being independence in 1971, the development for Bangladesh was formidable. The challenge for the increasing population growth, food shortage, natural disaster, aid dependency, widespread poverty is difficult to meet up in Bangladesh. Agriculture plays a great role to mitigate these types of problems. In FY 1978-1979, the contribution of agriculture sector in GDP is 44.9 percent where manufacturing is 18.2 percent (Ahmed et al., 2011) [1]. In FY 1998-1999, the contribution of manufacturing sector is 25.7 percent which is greater than agricultural sector (25.3 percent). In FY 2008-2009, the contribution of manufacturing sector in GDP is 29.7 percent (Ahmed et al., 2011) [1]. Actually, the involvement of the industry sector to Bangladesh economy is now at an increasing trend. Bangladesh Bureau of Statistics have identified fifteen industrial sector includes mining and quarrying, manufacturing, construction, electricity-gas, water supply. From these sectors, the contribution of the manufacturing sector is the highest (Islam, 2004) [2]. Different types of industries like sugar, readymade garments, knitwear, jute, tea, newsprint, leather goods, ceramics, modern chemical and pharmaceutical plants, bakery, and shrimp processing and so on are available in Bangladesh. Now it is expected that this upward growth trend of the industrial sector will help to achieve the national growth rate at a higher level.

Bakery is one of the manufacturing sectors of Bangladesh. Flour based food baked in an oven such as pastries, bread, cakes and pies are made in bakery firms. There are 751.23 thousands population in Khulna City Corporation Area (BBS, 2013). To supply the snack item for the city dwellers the bakery sector plays an important role. They prepare various delicious items which are really tasty and liked by the people of all ages of people. Especially the school going student are benefited from the bakery industry as they need snack in their tiffin time. So this sector is serving the people as well as doing business. Day by day the number of bakeries is increasing in all parts of Bangladesh. At present there are 49 bakeries in different brand name in south-west region(BBS, 2013) [3].These bakeries have different branches all over the south-west region. In Khulna city Baganbari, Sheikhpara, Kaylaghat, Fulbariget, Doulatpur, Boira are famous places for bakery production. This study is concerned about the productivity assessment of bakery firms. Authors choose Khulna city as study area.

\subsection{Objective Of The Study}

1. To analyze the productivity status of bakery firms

In this case, to analyze the productivity of bakery firms authors use Cobb-Douglous production function.

\section{Literature Review}

Manufacturing sector is playing a great role to accelerate economic growth and to reduce poverty. Capital goods, intermediate goods and most of the consumers good are produced by manufacturing sector (Lewis and Soligo, 1965) [4]. Manufacturing sector retains productivity growth, increasing returns to scale and 
rapid technological change (Weiss, 1988) [5].The bakery firm is one of the manufacturing firms in Bangladesh. It plays a dominant role for enhancement of economic growth, especially in case of employment generation, income generation and distribution of necessity foods (Rais et al., 2013) [6]. Marić et al. (2009) comment that a baking firm is generally related with production of different products that everyday find their place on the market [7]. He comments that bakery and confectionery play a crucial role in the beginning stage of industrialization by their backward and forward linkage besides the direct impact on employment and supplying necessary foods in both urban area and rural area (Irfana, 2012) [8].

Michael et al. (2014) state that the Cobb-Douglas production function means a production function which is widely used to represent the relationship between the amounts of two or more inputs, particularly physical capital and labor and the amount of output that can be produced by those inputs [9]. Biddle (2012) states Cobb-Douglas production function is used to measure the degree of returns to scale [10]. Hájková and Hurnik (2007) show that the two factor of Cobb-Douglas production function with Hicks-neutral technology is used including positive and diminishing marginal products with respect to labor and capital, constant returns to scale [11]. Labor, capital, energy, raw materials are playing great role in manufacturing sector (Boyd et al., 2001) [12].

Aghion et al. (1998) state in the light of Cobb-Douglas production function that returns to scale is a technical property of production [13]. It changes in output as a result of changing in all inputs where all inputs increase at a constant rate. If output increases by the same proportional change with the change of factors of production then it is called constant returns to scale. If output increases by more than that proportion of input then it is called increasing returns to scale. And if output increases by less than that proportion of input, there are decreasing returns to scale. Arrow et al. (1961) state that the Cobb-Douglas production function is the most widely used production function in any empirical work [14]. Murthy (2002) criticizes about the Cobb-Douglas production function. He states that the function cannot handle a large number of inputs. This function assumes constant returns to scale and is based on restrictive assumptions of perfect competition in the factor and product market. He also states that the Cobb-Douglas production function cannot measure technical efficiency levels and growth very effectively. Labor and capital are correlated and the estimation is bound to be biased. Instead of these limitations this production function is most widely used tool for productivity assessment [15].

Onwumere et al. (2012) consider capital as a very important variable for enhancing the production of bakery firm [16]. Capital mobilization is highly emphasized for the expansion of bakery product. They also emphasize about advanced technologies, extended market share through huge investment, adoption of new processing production technologies that increase the production volume and all for this capital is necessary. Aluko (1972) in his paper emphasize capital accumulation as an important factor to increase aggregate income. $\mathrm{He}$ also states that for subsequent development in baking firms capital mobilization should be given more importance [17].

Payne (2003) states that labor productivity are highly needed for a high scale of production. Labor is the active variable of any firm. Labors are responsible for the enhancement of growth especially in baking firms. He also shows that employment in the baking firms was increased 8 percent from 1998 to 2001 due to labor's productivity in baking firm. Bakery Production tends to be labor-intensive because the product bears short span of life and it requires frequently inventory turnover [18]. Kunze et al. (1995) also emphasize on labor productivity in any firm. They show the labor productivity per hour in their study. The labor productivity measures the changes in the relationship between output and the hours expended in producing that output. In their study they find a positive relationship between labor and production in a firm [19].

Payne (2003) in his paper shows energy cost is one of the important factors in baking firms. He says that most of the bakery products are baked in high temperature ovens and it causes energy cost with a huge amount which has an adverse effect on production [18]. These problems reduce the production of baking firms. Masanet (2012) reveals that energy efficiency plays a great role for reducing the cost in baking firms. He emphasizes that to increase the quality of products, increased production and increased process efficiency there is no alternative to using energy efficient technologies. If energy is used efficiently the cost of production of baking industry will be reduced as well as energy cost will also be reduced. According to him, if this cost is invested in any other productive purpose the productivity of baking firm will be increased in a great extent [20].

Haider (2010) urges raw materials help to build a strong relationship between suppliers and manufactures because manufactures have to collect raw materials from the supplier frequently. He also emphasizes about the distance between suppliers and manufactures of raw materials which also plays a great role in case of production [21]. Vizitiu et al. (2012) state that raw materials is extremely important for baking firms because without it, it is impossible to make the baking final products but quality of raw materials should be emphasized also to get the final product efficiently. If quality is good the output will also be good and that compete with the other product very effectively and sustainable development of product in the market is enhanced [22]. Payne (2003) mentions the cost of raw materials should be taken under consideration. Flour is responsible for 15 percent or 20 percent cost of production in baking firms which produce bread and roll only. 
He estimates that it the quality of the raw material is good then that types of raw materials should be collected for the development of the output [18].

\subsection{Study Area}

\section{Methodology}

From Khulna region authors purposively choose area of Khulna City Corporation as study area. The total area under Khulna City Corporation is 64.78 square kilometers. There are 31 wards and 184 mahallah under Khulna City Corporation area. The study area of the author is conducted concerning the bakery firm of Khulna region. In Khulna city, bakery products are produced in Baganbari, Sheikhpara, Kaylaghat, Doulatpur, Fulbarigate, Boira. Total 40 samples are purposively selected for the study. The Map 1represents the map of Khulna City Corporation:

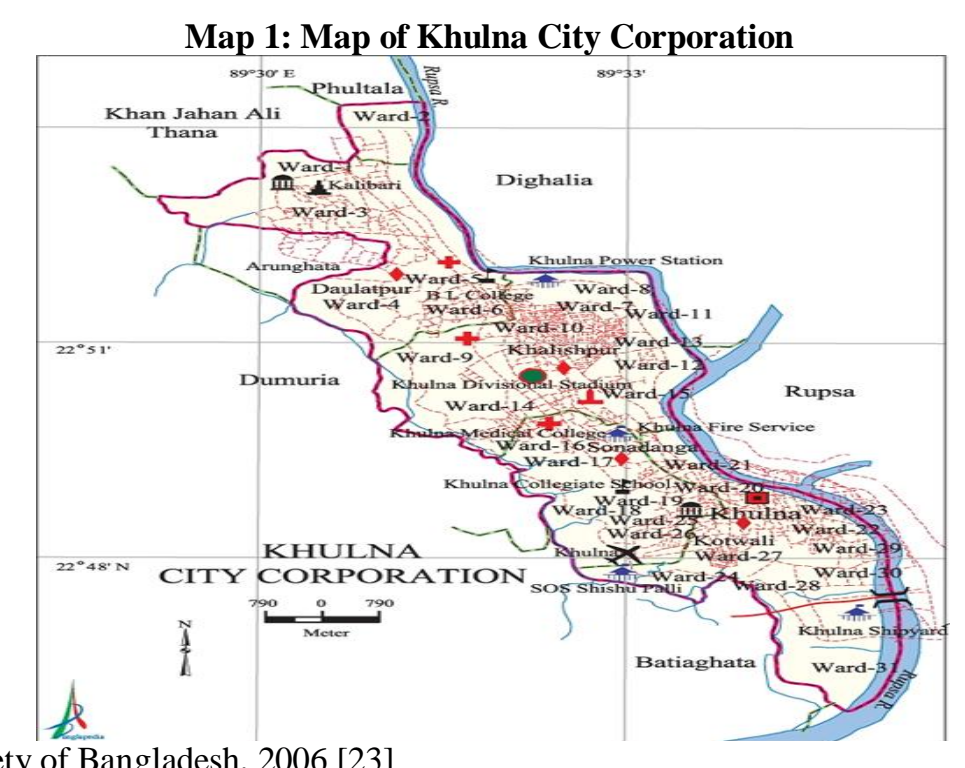

Source: Asiatic Society of Bangladesh, 2006 [23]

\subsection{Sampling Frame}

The total baking firms in south-west region is 49 holding different brand name (BBS 2013) [3]. They are operating their business with their several branches all over the south-west region. Authors choose Khulna region as study area. Authors apply convenience sampling method for data collection. The total sample size for productivity assessment of bakery firm is 40. The time period for data collection is August and Septembor of 2014. The data is cross-section in nature. Data is collected from recall method. Production and input use pattern of bakery firms of last 6 month (January to June of 2014) is bringing under consideration for the research purpose. Authors develop a structured questionnaire for data collection that comprises information about bakery firms' production pattern, use of machinery, input profile, educational qualification of labor, training, salary, total sales, total cost, cost of capital, price of products, raw materials cost, labor cost, initial investment, energy input etc.

\subsection{Productivity Assessment}

Authors apply Cobb-Douglas production function for productivity analysis. The generalized form of Cobb-Douglas production function is depicted in equation 1:

$$
\mathbf{Y}_{\mathbf{i}}=\boldsymbol{\beta}_{\mathbf{0}} \mathbf{L}^{\boldsymbol{\beta}_{1}} \mathbf{K}^{\boldsymbol{\beta}_{2}} \mathbf{e}^{\mathrm{u}_{\mathbf{i}}}
$$

A brief discloser of both dependent and explanatory variable is depicted in Table 1. In Table 1 four inputs i.e. labor, capital, raw materials and energy are considered as explanatory variable. All of the explanatory variables are measured in BDT. Dependent variable for the model is output. It is also measured in BDT. Considering four explanatory variables Equation 1 can be re-written as:

$$
\mathbf{Y}_{\mathbf{i}}=\boldsymbol{\beta}_{\mathbf{0}} \mathbf{L}^{\boldsymbol{\beta}_{1}} \mathbf{K}^{\boldsymbol{\beta}_{2}} \mathbf{R M}^{\boldsymbol{\beta}_{3}} \mathbf{E N}^{\boldsymbol{\beta}_{4}} \mathbf{e}^{\mathbf{u}_{\mathbf{i}}}
$$

Here, in Equation $3 \mathrm{i}$ is number of bakery firms, $\beta_{0}$ is intercept term, $\beta_{1}, \beta_{2}, \beta_{3}$ and $\beta_{4}$ are slope coefficient for labor, capital, raw materials and energy respectively. However, $u_{i}$ is the stochastic disturbance term. To transform the non-linear equation into linear form $\ln$ is added both side of Equation 2 and we obtain Equation 3 as follows: 


$$
\ln Y_{i}=\beta_{0}+\beta_{1} \ln L+\beta_{2} \ln K+\beta_{3} \ln R M+\beta_{4} \ln E N+u_{i}
$$

Table 1: Variable Description

\begin{tabular}{|c|c|c|c|c|}
\hline \multicolumn{2}{|l|}{ Variable } & \multirow{2}{*}{$\begin{array}{l}\text { Unit of } \\
\text { measurement }\end{array}$} & \multirow[t]{2}{*}{ Literature } & \multirow[t]{2}{*}{ Expected Sign } \\
\hline Dependent & Independent & & & \\
\hline \multirow{8}{*}{ Production } & \multirow[t]{2}{*}{ Labor } & \multirow[t]{2}{*}{ BDT } & Kunze et al. (1995) & + \\
\hline & & & Payne (2003) & + \\
\hline & \multirow[t]{2}{*}{ Capital } & \multirow[t]{2}{*}{ BDT } & Onwumere et al.(2012) & + \\
\hline & & & Aluko (1972) & + \\
\hline & \multirow[t]{2}{*}{ Energy } & \multirow[t]{2}{*}{ BDT } & Payne (2003) & - \\
\hline & & & Masanet (2014) & + \\
\hline & \multirow[t]{2}{*}{ Raw materials } & \multirow[t]{2}{*}{ BDT } & Vizitiu et al. (2012) & + \\
\hline & & & Chandan (1997) & + \\
\hline
\end{tabular}

Source: Authors' compilation

\subsection{Formation of Joint Hypothesis}

The researchers apply joint hypothesis test to trace out whether the change in inputs creates any change in the level of output.

Null Hypothesis, $\mathbf{H}_{\mathbf{0}}: \boldsymbol{\beta}_{\mathbf{i}}=\mathbf{0}$

The joint hypothesis test is applied for Cobb-Douglas production function. The value of $F$ statistics is bringing under consideration for joint hypothesis testing in the paper.

\subsection{Returns to Scale Assessment}

Returns to scale designate how percentage change in inputs enhances percentage change in output. Returns to scale are of 3 types:

1. Constant returns to scale

2. Increasing returns to scale

3. Decreasing returns to scale

Cobb-Douglas production function is very prominently used tool for returns to scale assessment (Chowdhury, 2010) [24]. The summation of the slope coefficient of Cobb-Douglas production function gives us right direction about returns to scale. The mechanism for returns to scale estimation is as follows:

$\beta_{1}+\beta_{2}+\beta_{3}+\beta_{4}=1$ Indicates constant returns to scale

$\beta_{1}+\beta_{2}+\beta_{3}+\beta_{4}>1$ Indicates increasing returns to scale and

$\beta_{1}+\beta_{2}+\beta_{3}+\beta_{4}<1$ Indicates decreasing returns to scale.

\subsection{Heteroscedasticity Test}

\section{Data Analysis}

Breusch-Pagan / Cook-Weisberg test for heteroscedasticity:

Ho: Constant variance

$\operatorname{chi}^{2}(1)=1.94$

Prob $>\mathrm{chi}^{2}=0.1639$

The above calculation indicates that there is no heteroscedasticity. The error term $\mathrm{u}_{\mathrm{i}}$ has constant variance i.e. the data is homoscedastic. Here the probability value manifests acceptance of null hypothesis which implies that there is no heteroscedasticity.

\subsection{Multicollinearity Test}

Table 2: Variance Inflation Factor

\begin{tabular}{llrr}
\hline & Variable & VIF & 1/VIF \\
\hline In Labor & 4.72 & 0.211668 \\
ln Captial & 6.31 & 0.15854 \\
ln Raw Materials & 3.11 & 0.322038 \\
ln Energy & 4.43 & 0.22553 \\
\hline \multicolumn{2}{r}{ Mean VIF } & 4.64 & \\
\hline
\end{tabular}

Source: Authors' compilation

Table 2 shows that the mean VIF is 4.64. It is known to us that if the mean value of VIF is more than 10 then there is multicollinearity. But some researchers argue that if the mean VIF is more than 2 then there is 
multicollinearity. For proper justification of the presence of multicollinearity author runs a correlation matrix. It is depicted in Table 3 .

Table 3: Correlation Matrix for Explanatory Variables

\begin{tabular}{lrrrr}
\multicolumn{5}{c}{ Table 3: Correlation Matrix for Explanatory } \\
\hline Variables & $\ln ($ Labor) & $\ln$ (Energy) & $\ln$ (Raw material) & $\ln ($ Capital) \\
\hline $\ln$ (Labor) & 1.0000 & & & \\
$\ln$ (Energy & $0.76^{* * *}$ & 1.0000 & & \\
$\ln$ (Raw Materials) & $0.77^{* * *}$ & $0.76^{* * *}$ & 1.0000 & 1.0000 \\
$\ln$ (Capital) & $0.86^{* * *}$ & $0.85^{* * *}$ & $0.74^{* * *}$ & \\
\hline
\end{tabular}

Source: Authors' compilation

N. B.: *** $\mathrm{p}<0.01$

Table 3 depicts the correlation matrix of explanatory variables. The degrees of correlation between labor-energy, labor-raw materials and labor-capital is $0.76,0.77,0.86$ respectively. They are significant at 1 percent level of significance. The degrees of correlation for energy-raw materials, energy-capital are 0.76 and 0.85 respectively. They are also significant at 1 percent level of significance. Besides the degree of correlation between raw materials-capital is 0.74 . It is also significant at 1 percent level of significance. To deal with the problem of multicollinearity either researchers have to increase their sample size or apply add drop method for regression analysis considering the explanatory variable. Authors concentrate on the later approach to deal with the problem of multicollinearity.

\subsection{Regression Analysis}

Table 4 depicts output elasticity of several inputs. In this paper for productivity assessment authors consider labor, capital, raw materials and energy as explanatory variable and output as independent variable. All of the variables are measured in BDT. Here authors apply add drop method to conduct regression analysis as there is problem of multicollinearity. Table 4 depicts that all explanatory variables in model 1 to model 6 are statistically significant at 1 percent level of significance.

Table 4: Production Function Estimation

\begin{tabular}{|c|c|c|c|c|c|c|c|c|}
\hline & & Model 1 & Model 2 & Model 3 & Model 4 & Model 5 & Model 6 & Model 7 \\
\hline ln labor & $\beta_{1}$ & $\begin{array}{l}0.589 * * * \\
(0.216)\end{array}$ & & $\begin{array}{l}0.396 * * * \\
(0.125)\end{array}$ & $\begin{array}{l}0.643 * * * \\
(0.158)\end{array}$ & & & $\begin{array}{l}0.156 \\
(0.161)\end{array}$ \\
\hline In Capital & $\beta_{2}$ & $\begin{array}{l}0.236 * * * \\
(0.086)\end{array}$ & & & & $\begin{array}{l}0.252 * * * \\
(0.086)\end{array}$ & $\begin{array}{l}0.177 * * * \\
(0.044)\end{array}$ & $\begin{array}{l}0.096^{*} \\
(0.038)\end{array}$ \\
\hline $\begin{array}{l}\text { ln Raw } \\
\text { materials }\end{array}$ & $\beta_{3}$ & & $\begin{array}{l}0.897 * * * \\
(0.119)\end{array}$ & $\begin{array}{l}0.887 * * * \\
(0.123)\end{array}$ & & & $\begin{array}{l}0.866 * * * \\
(0.109)\end{array}$ & $\begin{array}{l}0.775^{* * *} \\
(0.129)\end{array}$ \\
\hline In Energy & $\beta_{4}$ & & $\begin{array}{l}0.249 * * * \\
(0.077)\end{array}$ & & $\begin{array}{l}0.382 * * * \\
(0.101)\end{array}$ & $\begin{array}{l}0.351 * * * \\
(0.351)\end{array}$ & & $\begin{array}{l}0.103 \\
(.100)\end{array}$ \\
\hline F value & & 54.54 & 124.87 & 124.05 & 65.17 & 53.08 & 140.53 & 70.46 \\
\hline $\mathrm{R}^{2}$ & & 0.7317 & 0.8619 & 0.8612 & 0.7652 & 0.7263 & 0.8754 & 0.8812 \\
\hline
\end{tabular}

Source: Authors' compilation

N.B.: Standard errors in parentheses, $* * * \mathrm{p}<0.01, * \mathrm{p}<0.10$

In Table 4 at model 7 all explanatory variables are included for regression analysis. Here capital and raw materials are statistically significant at 10 percent and 1 percent level of significance respectively. Now if we consider labor, raw materials and energy as constant then a one percent increase in capital input leads to an average 0.096 percent increase in the production output. In the other side if labor, capital and energy are considered as constant, then a one percent increase in raw materials input leads to an average of 0.775 percent increase in the total production level. So availability of raw materials is a very important factor of production. If raw materials are available the productivity of bakery firms will boost up. The Table 4 also shows the value of $R^{2}$ for model 1 to model 7 . These values of $R^{2}$ depicts the percentage of total variation in $\mathrm{Y}$ is explained by the explanatory variables i.e. labor, capital, raw materials, energy for Model 1 to Model 7.

\subsection{Joint Hypothesis Testing}

For this study, researchers apply the joint hypothesis test to trace out whether the change in explanatory variable creates any change in the level of overall production of output.

Null Hypothesis, $\boldsymbol{H}_{\mathbf{0}}: \boldsymbol{\beta}_{\boldsymbol{i}}=\mathbf{0}$

All slope coefficients are zero that implies factors of production are not related with output.

Alternate Hypothesis: $\boldsymbol{H}_{\boldsymbol{A}}: \boldsymbol{\beta}_{\boldsymbol{i}} \neq \mathbf{0}$

All slope of coefficient are not zero that implies factors of production are related with output. 
Table 5: Result of Joint Hypothesis Test

\begin{tabular}{cccc}
\hline Model No. & Tabulated F Value & Calculated F Value & Decision \\
\hline Model -1 & 5.21 & 54.54 & $\mathrm{H}_{0}$ is Rejected \\
Model -2 & 5.21 & 124.87 & $\mathrm{H}_{0}$ is Rejected \\
Model -3 & 5.21 & 124.05 & $\mathrm{H}_{0}$ is Rejected \\
Model -4 & 5.21 & 65.17 & $\mathrm{H}_{0}$ is Rejected \\
Model -5 & 5.21 & 53.08 & $\mathrm{H}_{0}$ is Rejected \\
Model -6 & 5.21 & 140.53 & $\mathrm{H}_{0}$ is Rejected \\
Model -7 & 3.89 & 70.46 & $\mathrm{H}_{0}$ is Rejected \\
\hline
\end{tabular}

Source: Authors' compilation

Table 5 depicts result of joint hypothesis test. The results manifest rejection of null hypothesis for model 1 to model 7. All of the model accept alternative hypothesis at 1 percent level of significance with their corresponding explanatory variables and degrees of freedom. In each of the case calculated $F$ value is greater than tabulated $F$ value. So it can be said that all the inputs are related with output and it is significant at 1 percent level of significance.

\subsection{Measurement of Returns to Scale}

Authors consider model 7 for assessment of returns to scale of bakery firms. Four explanatory variables are considered to estimate the production function and these are labor, capital, raw materials and energy. Here $\beta_{1}$ is the coefficient of labor, $\beta_{2}$ is the coefficient of capital, $\beta_{3}$ is the coefficient of raw materials and $\beta_{4}$ is the coefficient of energy. In this case, $\beta_{1}+\beta_{2}+\beta_{3}+\beta_{4}=1$ indicates constant returns to scale, $\beta_{1}+\beta_{2}+\beta_{3}+$ $\beta_{4}>1$ indicates increasing returns to scale and $\beta_{1}+\beta_{2}+\beta_{3}+\beta_{4}<1$ indicates decreasing returns to scale. Here,

Source: Authors' compilation

Table 6: Rate of Returns to Scale

\begin{tabular}{cr}
\hline Coefficient (Variables) & Value of the Variables \\
\hline$\beta_{1}$ & 0.156 \\
$\beta_{2}$ & 0.096 \\
$\beta_{3}$ & 0.775 \\
$\beta_{4}$ & 0.103 \\
\hline Total & $\mathbf{1 . 1 3 0}$ \\
\hline
\end{tabular}

The table 6 shows that $\beta_{1}+\beta_{2}+\beta_{3}+\beta_{4}=1.130$ which is greater than 1 that means in bakery firms there is appearance of increasing returns to scale. So for the bakery firms increasing returns to scale implies that, a 1 percent increase in inputs (labor, capital, raw materials, and energy) causes an increase in output more than 1 percent.

\section{Concluding Remarks}

Authors have found many problems while collecting data from the baking firms in Khulna region. The authors have also given some recommendations to the baking firms to overcome the problems associated with their production activities. The recommended solution to mitigate the problems of the bakery firms are disclosed in later segment of the paper. Most of the baking firms in the study area have limited number of labor. For this reason production is lower. So, more labor should be employed to increase the volume of production. The data also provide strong support in favor of the recommendation. Model 1, 3 and 4 shows positive associations between labor and firm level output. If capital, raw materials and energy are considered as constant, then a one percent increase in labor input leads to an average of $0.589,0.396$ and 0.643 percent increase in the level of total production for model1, model 2 and model 3 respectively. It is also seen that most of the labors in the baking firms are not skill enough and they have low educational qualification as well. For this, they have low efficiency in case of production. So the firms should employ skill labor and literate people for increasing the production level.

Very few firms in the study area give financial and nonfinancial motivation to the workers. This cause lowers the production level. So the firms should give financial and nonfinancial motivation to the workers. The firms should have technological innovation for better production. But in most of the case the production technique, patterns and practice of raw materials use, use of different cooking instrument are not up to date. The bakery owners motive is profit maximization rather wealth maximization. However, the main motive of the firm owners should be wealth maximization. There are many approaches of wealth maximization like purchasing more machinery and vehicle, employing more labor, increasing their land area, developing skill of labor through training and so on. If wealth is maximized then the volume of profit will be increased. So, the firm owners 
should concentrate on wealth maximization. From field survey authors come to learn that the firms bear no cost for research and development activities. But for increasing the volume of production of the firms, the firms should bear some cost in case of research and development considering the aspect of product line development, product quality development, increase output using less input, increase distribution channel, increase market share. Volume of raw materials should be increased as it is seen that holding all other explanatory variables as constant a one percent increase in raw materials have positive relation with output level of bakery firms. Environment of the baking firms are not well in the study area. Most of the cases the background of production is not hygienic. For this reason the demand for baking goods is decreasing. So for increasing demand, the firms should develop their working environment and also concentrate on the hygiene of food production. To make the worker aware about the hygiene practice bakery malik somity can arrange several seminars, meetings and workshop.

In the study, authors also finds that most of the baking firms have lower number of labor and low amount of capital. The authors also show that among the cost of raw materials, energy, labor raw materials bear the largest cost of total cost of the baking firms. Author also finds that lack of educational qualification, lack of skill labor, lack of financial and nonfinancial motivation, political instability are the main hindrance for the baking firms in the author's study area. The study draws that cheap labor unit, cheap accommodation facilities, low political instability, uninterrupted electricity supply, water supply are the main advantages for the firms to sell their final product and to make a good profit. Baking firms supply foods at a reasonable price than that of any first food shop or restaurant. So, more or less people of all walks of life can afford it.

Baking firms play a great role in our national economy and employment generation. This sector is also helpful to meet up daily demand of food of domestic people of our country as well as in abroad. To supply the snack items of the city dwellers, baking firms are playing a significant role. So with the passage of time, bakery firms are growing up at an increasing rate because the product of baking firms gain huge public demand. At present time period it is an important body that supplies tiffin in different schools and offices. Many first food shops also rely on them for supply of fresh bun, butter nan etc. The major product they serve to their customer is biscuit, chanachur, paties, danish, cake, bun, loaf etc. Many baking firms supply birthday cake by order of it's customer at a very reasonable price. But authors cannot over look the bad practice of baking firms. First of all the production mechanism does not consider hygiene practice. In many cases they supply date expired food items. They also use several chemicals like food color, baking soda, sytric, testing salt etc. to prepare the food. Prolong intake of such comical food have negative effect on human health. To solve the problem government should come forward to cure it.

The authors have estimated and shows that the association of inputs i.e. labor, capital, raw materials and energy have positive relation with the production. So the amount of raw materials, labor, capital and energy supply should be increased for a high level of production. Author finds that cheap labor unit, cheap accommodation facilities, lower political instability, electricity supply, water supply are the main advantages for the firms to sell their final product and to make a good profit. However for wealth maximization and good profit, authors think that the firms should give emphasize on skill labor, technological innovation, financial and non financial motivational strategy, good environment, educational qualification of the labor and staff.

\section{References}

[1]. N. Ahmed, Z. Bakht, and M. Yunus, Size structure of manufacturing industry and implications for growth and poverty, Bangladesh Institute of Development Studies, 2011, 1-32.

[2]. R. Islam, The nexus of economic growth, employment and poverty reduction: An empirical analysis, Recovery and Reconstruction Department, International Labour Office, 2004.

[3]. BBS, 'District Statistics 2011', Bangladesh Bureau of Statistics, Ministry of Planning, Government of the Peoples Republic of Bangladesh, Dhaka, Bangladesh, 2013.

[4]. S.R. Lewis, and R. Soligo, Growth and structural change in Pakistan manufacturing industry, 1954-1964, The Pakistan Development Review, 1965, 94-139.

[5]. J. Weiss, Industry in developing countries: theory, policy and evidence (Croom Helm London and New York, 1988).

[6]. M. Rais, S. Acharya, and N. Sharma, Food processing industry in india: s\&t capability, skills and employment opportunities, Journal of Food Processing and Technology, 4(260), 2013, 12-13.

[7]. A. Marić, S. Arsovski, and J. Mastilović, Contribution to the improvement of products quality in baking industry, International Journal for Quality research, 3(3), 2009, 1-8.

[8]. K.D. Irfana, Production and profitability of flour confectionary products in different sizes of bakery industry in Marathwada region (MS) India, Science Research Reporter, 2(2), 2012,13-24

[9]. A. Michael, D. Kuznetsov, and S. Mirau, Analysis of the irrigation water price in rice production Tanzania, Applied and Computational Mathematics, 3(4), 2014, 177-185.

[10]. J. Biddle, The Cobb-Douglas Regression and the Measurement of Economic Growth and its Causes, 2012, 1-54.

[11]. D. Hájková, and J. Hurník, Cobb-Douglas production function: the case of a converging economy, Czech Journal of Economics and Finance (Finance a uver), 57(9-10), 2007, 465-476.

[12]. W. Boyd, W.S. Prudham, and R.A. Schurman, Industrial dynamics and the problem of nature, Society \& Natural Resources, 14(7), 2001, 555-570.

[13]. P. Aghion, P. Howitt, and C. García-Peñalosa, Endogenous growth theory, (MIT press, 1998). 
[14]. K.J. Arrow, H.B. Chenery, B.S. Minhas, and R.M. Solow, Capital-labor substitution and economic efficiency, The Review of Economics and Statistics, 1961, 225-250.

[15]. K. Murthy, Arguing a case for Cobb-Douglas production function, Review of Commerce Studies, 20-21(1), 2002, 75-91.

[16]. J. Onwumere, A. Nwosu, and J. Nmesirionye, Assessment of the effect of external capital mobilization on the equipment investment of bakery enterprises in South Eastern Nigeria, Management, 1(9), 2012. 83 - 89.

[17]. S. Aluko, Determinants of saving income ratio, Staff seminar: Faculty of Social Science Obafemi Awolowo University., Ilelfe, $1972,9-15$

[18]. P. Warren, Industry and Trade Summary report on bakery products, 2003, United States.

[19]. K. Kunze, M. Jablonski, and V. Klarquist, BLS modernizes industry labor productivity program, Monthly Lab. Rev., 118, 1995, 312.

[20]. E. Masanet, Energy Efficiency improvement and cost saving opportunities for the baking industry, $2012,1-111$.

[21]. M.Z. Haider, Raw material sourcing and firm performance: evidence from manufacturing firms in south-west Bangladesh, The Bangladesh Development Studies, 33(4), 2010, 51-61.

[22]. D. Vizitiu, M.. Ognean, and I. Danciu, Rheological evaluation of some laboratory mills, Bulletin of University of Agricultural Sciences and Veterinary Medicine Cluj-Napoca, Agriculture, 69(2), 2012, 455-460.

[23]. Asiatic Society of Bangladesh, Banglapedia, National Encyclopedia of Bangladesh, Asiatic Society of Bangladesh, Dhaka, 2006.

[24]. N.T. Chowdhury, The relative efficiency of water use in Bangladesh agriculture, Quarterly Journal of International Agriculture, 49(2),2010, 147-164. 